\title{
Isparta Koşullarında Kavuzsuz Arpa (Hordeum vulgare L. var. nudum) Çeşit/Hatlarının Verim ve Bazı Tarımsal Özelliklerinin Belirlenmesi
}

\author{
Tuğçe Gümüş ${ }^{1 * \dagger}$, İlknur Akgün² \\ 1* Isparta Uygulamalı Bilimler Üniversitesi, Ziraat Fakültesi, Tarla Bitkileri Bölümü, Isparta, Türkiye, (ORCID: 0000-0003-2747-2086), tjeeg@icloud.com

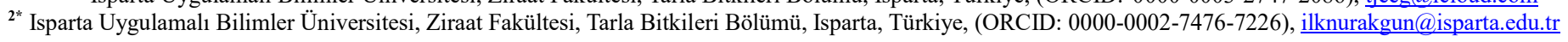

(İlk Geliş Tarihi 4 Kasım 2021 ve Kabul Tarihi 12 Aralık 2021)

(DOI: 10.31590/ejosat.1019172)

ATIF/REFERENCE: Gümüş, T. \& Akgün, İ. (2021). Isparta Koşullarında Kavuzsuz Arpa (Hordeum vulgare L. var. nudum) Çeşit/Hatlarının Verim ve Bazı Tarımsal Özelliklerinin Belirlenmesi. Avrupa Bilim ve Teknoloji Dergisi, (31), 624-628.

$\ddot{\mathbf{O} z}$

Bu araştırma 2019-2020 üretim yılında Tesadüf Blokları Deneme desenine göre üç tekerrürlü olarak Isparta ekolojik koşullarında yürütülmüştür. Çalışmada farklı kavuzlu arpa (iki sıralı Aydan Hanım ve Tosun Paşa) ve kavuzsuz arpa (Yalın, INBYT-6, INBYT-16, INBYT-18, ABA-7 ve ABA-8) çeşit/hatlarında tane verimi ile bazı agronomik özellikler incelenmiştir. Araşırmada genotiplere 10 kg/da azotlu, $6 \mathrm{~kg} /$ da hesabıyla fosforlu gübre uygulanmış ve $500 \mathrm{adet} / \mathrm{m}^{2}$ tohum olacak şekilde ekim yapılmıştır. Araştırma sonuçlarına göre; tane verimi $156.4-465.5 \mathrm{~kg} / \mathrm{da}$, hasat indeksi \%26.86-31.37, hektolitre ağırlığı 68.04-78.44 kg, bin tane ağırlığı 28.70-43.33 g, başakta tane sayısı 19.01-26.80 adet ve ham protein oranı \%12.58-15.75 arasında değiştiği belirlenmiştir. İncelenen özellikler yönünden çeşit/ hatlar arasındaki farklılıklar istatistiksel yönden önemli bulunmuştur. En yüksek tane verimi INBYT-18 hattında belirlenmiş, ancak bu hat ile Tosun Paşa ve ABA-8 genotipleri arasındaki fark önemsizdir. Yine kavuzlu çeşitlerden daha yüksek oranda ham protein içeren (INBYT-6 ve ABA-7) hatların olduğu belirlenmiştir.

Anahtar Kelimeler: Kavuzsuz arpa, Tane verimi, Agronomik özellikler, Kalite.

\section{Determination of Yield and Some Agricultural Characteristics of Hull-less Barley (Hordeum vulgare L. var. nudum) Varieties/Lines in Isparta Conditions}

\begin{abstract}
This research was carried out in Isparta ecological conditions in the 2019-2020 production years according to the compleletely blocks design with three replications. In the study, grain yield and some agronomic characteristics of different hulled barley (two-row Aydan Hanım and Tosun Paşa) and hull-less barley (Yalın, INBYT-6, INBYT-16, INBYT-18, ABA-7 and ABA-8) cultivars/lines has been determined. In the study, $10 \mathrm{~kg} / \mathrm{da}$ of nitrogen and $6 \mathrm{~kg} / \mathrm{da}$ of phosphorus fertilizer were applied to the genotypes and $500 \mathrm{seeds} / \mathrm{m}^{2}$ of seeds were sown. According to the research results, it was found that varied between; grain yield $156.4-465.5 \mathrm{~kg} / \mathrm{da}$ thousand grain weight $28.70-43.33 \mathrm{~g}$, test weight $68.04-78.44 \mathrm{~kg}$, harvest index 26.86-31.37\%, grain number per spike 19.01-26.80 and crude protein rate between 12.58-15.75\%. Differences between varieties and lines were determined to be statistically significant. The highest grain yield was determined in INBYT-18 line But, with this line, Tosun Paşa and ABA 8 genotypes were statistically in the same group. It was determined that lines with higher crude protein content (INBYT-6 and ABA-7) than the husked varieties.
\end{abstract}

Keywords: Hull-les barley, Seed yield, Agronomic characters, Quality,.

\footnotetext{
* Bu çalışma Tuğçe Gümüş'ün yüksek lisans tezinden türetilmiştir ve ICAAW 2021'de sözlü olarak sunumu yapılmıştır.

† Sorumlu Yazar: tjeeg@icloud.com
} 


\section{Giriş}

Arpa, dünyada önemli derecede yetiştiriciliği yapılan serin iklim tahılları içerisinde yer almaktadır. Ülkemiz arpanın önemli gen merkezlerinden birisidir. Ayrıca, Dünya'da arpa üreten ilk 10 ülke arasında yer almaktadır. Genel olarak kışlık yetiştiriciliği yapılan arpa, ekiliş ve üretim miktarı olarak Dünya genelinde tahıllar içerisinde dördüncü, Türkiye'de ise ikinci sırada yer almaktadır. Dünyada arpanın ekim alanı yaklaşık 51.15 milyon hektar, üretim 159 milyon ton ve ortalama verim $310.8 \mathrm{~kg} / \mathrm{da}$ 'dır (Anonim, 2019). Türkiye'de arpanın ekiliş alanı 3.097.162 ha, üretimi ise 8.300 .000 tondur. Dekara ortalama verim $268 \mathrm{~kg} / \mathrm{da}$ olup dünya ortalamasının altındadır (Anonim, 2020). Kültüre alınan bitkilerin arasında ilk sıralarda olduğu bilinen arpa, binlerce yıl insan beslenmesinde kullanılmıştır. Anadolu topraklarında da kültürünün çok eski olduğu, anavatanının 'Bereketli Hilal' olarak adlandırılan ve Türkiye’yi de kapsayan İsrail, Ürdün, Filistin, Suriye, Irak ve İran gibi ülkelerin içinde bulunduğu coğrafi bölge olduğu bilinmektedir (Harlan ve Zohary, 1966; Gökgöl, 1969; Nesbitt ve Samuel, 1996).

Kültür bitkisi olarak bilinen arpanın, kavuzlu ve kavuzsuz olmak üzere 2 farklı formu mevcuttur. Arpa tanesinin buğday tanesinden temel farklılığı iç kavuz yapısının taneye sıkı bir şekilde yapışık olmasidir. $\mathrm{Bu}$ nedenle arpa, kavuzlu tane olarak adlandırılmaktadır. Kavuzsuz arpada (Hordeum vulgare L. var. nudum Hook. F) iç kavuzlar yoktur ya da çok ince bir yapıdadır. Kavuzsuz arpanın üretimi, ıslah çalışmaları, yem, gıda ve endüstriyel alanlarda kullanılması konularında birçok araştırmalar yapılmaktadır. Son yirmi yılda arpa, yulaf hariç diğer tahıllarla karşılaştırıldığında daha yüksek çözünür diyet lifleri içeriği nedeniyle nutrasötik(nutraceutical) tahıllar arasında yerini almıştır (Derakhshani vd., 2020). Değişen beslenme alışkanlıkları/tarzları ile birlikte nutrasötiklerin ve sağlıklı gıdaların önemi artmıştır. Arpa, diğer tahıllara (buğday ve pirinç) göre, daha yüksek beta glukanlar $(\beta-1-3 ; 1-4)$ ve çözünebilir lif içermektedir. Beta glukanların LDL Kolesterolü (lipoprotein kolesterol) azalttığı böylece kardiyovasküler hastalıklara karş1 koruyucu rol sağladığı ve kolon kanseri türlerine karşı koruma sağladığı bilinmektedir (Sarkar vd., 2015; Ames vd., 2008 Madhujith vd., 2007). Düzenli beta glukan tüketiminin kan şekerini düşürdüğü ve bu nedenle tip II diyabetin önlenmesinde yardımcı olduğu bildirilmektedir (Ames vd., 2008). Arpanın gelişmiş ve gelişmekte olan ülkelerin kentsel nüfusunda düzenli ve sağlıklı beslenme stilinin bir parçası olması beklenmektedir (Narwal vd., 2016). Bazı Afrika ülkelerinde ve Tibet bölgesinde arpa, temel gida olarakta tüketilmektedir (Ullrich, 2011).

Kavuzlu arpa, genel olarak hayvan beslenmesinde ve malt sanayisinde kullanılırken, işlenmesi daha kolay olan kavuzsuz arpalar, daha çok insan gıdası olarak kullanılmaktadır. Kavuzsuz arpa, klasik buğday ögütme metod ve ekipmanları ile kepek ve una kolaylıkla ayrılabilmektedir (Karaduman, 2006). Kavuzun çıkarılması ekstra çaba gerektirmekte ve besin kaybına neden olmaktadır. Arpanın gıda olarak doğrudan tüketimi için kavuzsuz çeşitler tercih edilmektedir. Özellikle işlenmiş ürünlerde istenmeyen tat ve renge neden olabilmektedir (Narwal vd., 2016). Kavuzsuz arpa sslah metodları, biyotik ve abiyotik streslere karşı daha iyi toleransla verimi artırmaya yönelik amaçlarla yapılmaktadır. Kavuzsuz arpanın Isparta ekolojik koşullarında denemeye alınması, üreticilere alternatif ürün sunulmasını ve ekim alanlarının artırılmasını sağlayabilir.
$\mathrm{Bu}$ çalışmada, kavuzlu ve kavuzsuz hat/çeşitleri Isparta ekolojik koşullarında tane verimi, verim öğeleri ve bazı kalite özellikleri yönünden incelenmiştir. Özellikle kavuzsuz arpa hatlarının bu ekolojik koşullara uyum yeteneğinin belirlenmesi ve tescilli çeşit ile karşılaştırılarak üstün olan hattın tespit edilmesi hedeflenmiştir.

\section{Materyal ve Metot}

\subsection{Materyal}

Bu çalışmada tohum materyali olarak, iki sıralı Aydan Hanım (kavuzlu), Tosun Paşa (kavuzlu), Yalın (kavuzsuz) tescilli arpa çeşitleri ile farklı Araştırma Enstitülerinden temin edilen (INBYT-6, INBYT-16, INBYT-18, ABA-7, ABA-8) 5 adet kavuzsuz arpa hattı kullanılmıştır.

\subsection{Metod}

Araştırma, Tesadüf Blokları Deneme Desenine göre 3 tekerrürlü olarak 15 Kasım 2019 tarihinde kurulmuştur. Çeşit/hatların 1000-tane ağırlığı ölçülerek, metrekarede 500 adet tohum olacak şekilde ekim mibzerle yapılmıştır. Parsel uzunluğu $5 \mathrm{~m}$, sira arası $18 \mathrm{~cm}$ olacak ve bloklar arasında $1.5 \mathrm{~m}$ mesafe şekilde ekim planlanmıştır. Dekara $10 \mathrm{~kg}$ hesabıyla azotlu, $6 \mathrm{~kg} / \mathrm{da}$ hesabıyla fosforlu gübre uygulanmıştır. Azotlu gübrenin yarısı ekimle birlikte, geri kalan yarısı ise sapa kalkma döneminde verilmiştir. Yabanc1 ot mücadelesi 150-200 cc/da aktif madde hesabıyla 2.4-D terkipli herbisit kullanılmıştır. Bitkiler mevsime bağlı yağışlar dışında susuz koşullarda yetiştirilmiştir. Hasat tam olum dönemine gelen parsellerde bitkiler el ile yapılmış ve tohumlar parsel harman makinesiyle harmanlanmıştır.

Araştırmada tane verimi, hasat indeksi (Genç vd., 1988), hektolitre ve bin tane ağırlığı (Sağsöz, 2000), kavuz oranı (Anonymous, 1987) ve protein oranı (Bremner, 1965; Kacar ve İnal, 2010) incelenmiştir.

Denemeden elde edilen verilerin varyans analizi, tesadüf blokları deneme desenine uygun olarak, MINITAB paket programı kullanılarak yapılmış, ortalamalar TUKEY testi ile karşılaştırılmıştır.

Denemenin yürütüldüğü dönemde (Kasım-2019-Temmuz2020) ortalama sicaklık $\left(11.36^{\circ} \mathrm{C}\right)$ aynı döneme ait uzun yıllar ortalamasından $\left(10.26{ }^{\circ} \mathrm{C}\right)$ yüksek, toplam yağış miktarı $(421.5$ $\mathrm{mm}$ ) ise aynı döneme ait uzun yıllar toplamından (uzun yıllar toplam yağış $498.2 \mathrm{~mm}$ ) daha düşük olduğu belirlenmiştir (Tablo 1).

Tablo 1. Uzun Yıllar ve Denemenin Yürütüldüğ̈̈ Yıllara ait Sicaklık, Nem ve Yağış Verileri

\begin{tabular}{|c|c|c|c|c|c|c|}
\hline \multirow[b]{2}{*}{ Aylar } & \multicolumn{3}{|c|}{ Uzun Yillar (1929 - 2020) } & \multicolumn{3}{|c|}{ Deneme Yılı 2019-2020 } \\
\hline & $\begin{array}{l}\text { Yağış } \\
(\mathbf{m m})\end{array}$ & $\begin{array}{c}\text { Sicaklık } \\
\left({ }^{\circ} \mathrm{C}\right)\end{array}$ & $\begin{array}{l}\text { Nem } \\
(\%)\end{array}$ & $\begin{array}{l}\text { Yağış } \\
(\mathbf{m m})\end{array}$ & \begin{tabular}{|c|} 
Sicaklık \\
$\left({ }^{\circ} \mathrm{C}\right)$
\end{tabular} & \begin{tabular}{|l|} 
Nem \\
$(\%)$
\end{tabular} \\
\hline Kasım & 44.8 & 7.8 & 69.9 & 28.6 & 9.8 & 71.6 \\
\hline Aralık & 86.7 & 3.6 & 76 & 45.3 & 4.6 & 77.5 \\
\hline Ocak & 81 & 1.8 & 75.3 & 74.1 & 1.4 & 70.6 \\
\hline Şubat & 67.6 & 2.9 & 71.7 & 71.4 & 3.8 & 75.2 \\
\hline Mart & 58.8 & 6 & 65.9 & 41.3 & 7.7 & 64.8 \\
\hline Nisan & 52.1 & 10.7 & 61.3 & 24.2 & 11.6 & 58.6 \\
\hline Mayıs & 57 & 15.4 & 59.2 & 92.1 & 16.1 & 57.1 \\
\hline Haziran & 34.3 & 19.9 & 52.7 & 42.6 & 20.3 & 52.3 \\
\hline Temmuz & 15.9 & 23.4 & 45.6 & 1.9 & 27 & 36.5 \\
\hline Ortalama & - & 10.16 & 64.17 & - & 11.36 & 62.68 \\
\hline Toplam & 498.2 & - & - & 421.5 & - & - \\
\hline
\end{tabular}


Deneme yerinin toprak özellikleri; tekstür bakımından killitınlı, kireççe zengin (\% 28.7), organik maddece fakir (\% 1.54), pH's1 7.66, fosfor bakımından fakir $(23.5 \mathrm{mg} / \mathrm{kg})$ ve potasyum (176.2 $\mathrm{mg} / \mathrm{kg}$ ) bakımından zengindir.

\section{Araştırma Sonuçları ve Tartışma}

\subsection{Tane Verimi}

Araştırmada tane verimi 156.4-465.5 kg/da arasında değişmiş ve genotipler arasındaki bu farklılık istatistiksel olarak önemli bulunmuştur $(\mathrm{P} \leq 0.01)$. En yüksek tane verimi kavuzsuz INBYT18 hattında belirlenmiş olmakla birlikte, ABA-8 ve Tosun Paşa genotipleri arasındaki fark istatistiksel olarak önemli değildir. En düşük birim alan tane verimi ise INBYT-6 hattında belirlenmiştir (Tablo 2).

Genotiplerin tane verimi genetik yapının yanında çevre faktörlerinden de etkilenebilmektedir (Sirat ve Sezer, 2009; Mut vd., 2014). Nitekim Yüksel ve İkincikarakaya (2020) tarafindan yapılan çalışmada tane verimi yıllara ve genotiplere göre değiştiğini (1. yıl 159.37-271.63-kg/da, 2. y1l ise 163.13-242.08 $\mathrm{kg} / \mathrm{da}$ ) bildirmiş̧lerdir. Yine Yalın kavuzsuz arpa çeşidinde tane veriminin lokasyonlara ve dozlara (Bursa 164.56-404.39 kg/da, Bakıkesir 80.03-378.41 kg/da) göre değiştiği belirlenmiştir (Kilercioğlu, 2020). Bu konuda yapılan çalışmalar incelendiğinde tane verimi 36.24-236.50 kg/da (Baydilli, 2017) ve 169.67-363.0 $\mathrm{kg} / \mathrm{da}$ (Çöken ve Akman, 2016) olarak bildirilmiştir.

\subsection{Hasat İndeksi}

Kavuzlu ve kavuzsuz arpa genotiplerinin ortalama hasat indeksi değerleri arasındaki farklıklar, istatistiksel yönden önemli olduğu belirlenmiştir $(\mathrm{P} \leq 0.01)$. Hasat indeksi ortalamaları \%26.86-31.37 arasında değişim göstermiştir. En yüksek hasat indeksi değeri ABA-8 hattı ve Yalın çeşidinde belirlenmiş olmakla birlikte, INBYT-16 hattı hariç diğer genotiplerle aynı grupta yer almıştır (Tablo 2).

Hasat indeksi tane verimi üzerine doğrudan etkili olup, hasat indeksinin yüksek olması istenmektedir (Ergün, 2005). Ancak hasat indeksi genotipe, çevre şartlarına ve kültürel uygulamalara göre değişebilmektedir. (Ulupınar, 2017; Altındal, 2014) Nitekim Yüksel (2017) tarafından 10 arpa genotipi kullanılarak sulu ve kuru koşullarda yürütülen araştırmada, hasat indeksinin yıllara ve yetiştirme koşullarına göre değiştiğini bildirmiştir (Hasat indeksi 1. y1l kuru koşullarda \%22.33-32.16, sulu koşullarda \%22.7933.54, 2. y1lda kuru koşullarda \%24.57-35.24 sulu koşullarda ise \%27.69-32.15). Bu konuda yapılan diğer çalışmalar incelendiğinde, hasat indeksi değerlerinin \%35.3-39.0 (Sirat ve Sezer, 2009), \%15.50-30.17 (Çöken ve Akman, 2016) arasında değiştiği tespit edilmiştir. Çalışma sonuçlarımıza göre genotiplere ait hasat indeksi ortalamaları \% 26.86-31.37 arasında olup ve literatür ile uyumlu olduğu görülmektedir.

Tablo 2.Kavuzlu ve Kavuzsuz Genotiplerde İncelenen Bazı Özelliklere Ait Ortalama Değerler

\begin{tabular}{|c|c|c|c|c|c|c|}
\hline Genotipler & Tane Verimi & Hasat İndeksi & Hektolitre & 1000-Tane Ağırlığı & Başakta Tane Sayısı & Ham Protein Oranı \\
\hline Aydan Hanım & $339.00 \mathrm{C}^{*}$ & $28.37 \mathrm{AB}^{*}$ & $70.51 \mathrm{~B}^{*}$ & $43.26 \mathrm{~A}^{*}$ & $25.91 \mathrm{~A}$ & $13.58 \mathrm{C}^{*}$ \\
\hline Tosun Paşa & $410.20 \mathrm{AB}$ & $28.79 \mathrm{AB}$ & $71.60 \mathrm{AB}$ & $43.33 \mathrm{~A}$ & $26.80 \mathrm{~A}$ & $12.69 \mathrm{D}$ \\
\hline Yalın & $354.90 \mathrm{BC}$ & $31.13 \mathrm{~A}$ & $75.07 \mathrm{AB}$ & $38.71 \mathrm{AB}$ & $24.44 \mathrm{AB}$ & 12.58 D \\
\hline ABA-8 & $461.40 \mathrm{~A}$ & 31.37 A & $78.44 \mathrm{~A}$ & $34.04 \mathrm{BC}$ & $19.96 \mathrm{BC}$ & $14.34 \mathrm{~B}$ \\
\hline INBYT-6 & $156.40 \mathrm{E}$ & $27.72 \mathrm{AB}$ & $71.07 \mathrm{AB}$ & $28.70 \mathrm{C}$ & $20.04 \mathrm{BC}$ & $15.75 \mathrm{~A}$ \\
\hline INBYT-16 & $360.40 \mathrm{BC}$ & 26.86 B & $70.21 \mathrm{~B}$ & $35.99 \mathrm{~B}$ & $19.24 \mathrm{C}$ & $14.35 \mathrm{~B}$ \\
\hline Ortalama & 351.33 & 29.13 & 71.85 & 36.56 & 21.83 & 14.03 \\
\hline
\end{tabular}

* Aynı sütunda aynı harfle gösterilen ortalamalar arasındaki fark istatistiksel olarak önemli değildir.

\subsection{Hektolitre}

Kavuzlu ve kavuzsuz hat/çeşitlerde hektolitre ağırlığı, istatistiksel olarak önemli farklılık göstermiştir $(\mathrm{P} \leq 0.01)$ ve 68.04-78.44 kg arasında değiştiği belirlenmiştir En yüksek hektolitre ağırlı̆̆ ABA-8 hattında belirlenmiş, bu hat ile Yalın, Tosun Paşa çeşitleri ve INBYT-6 hattı arasındaki farklılık istatistiksel olarak önemsiz bulunmuştur. En düşük hektolitre ağırlığ 1 ise ABA-7 hattında belirlenmiş olmakla birlikte ABA-8 hattı hariç diğer genotiplerle aynı grupta yer almıştır (Tablo 2).

Arpada önemli kalite kriterlerinden birisi hektolitre ağırlığıdır. Özellikle malt sanayisinde kullanıldığında hektolitre ağırlığının yüksek olması istenmektedir. Tanenin yoğunluğu ve şeklinin hektolitre ağırlığını etkileyebildiği bildirilmiştir (Öztürk vd., 2001). Hektolitre ağırlığı tanenin endosperm yapısına ve kavuz oranına bağlı olarak genotiplerde farklılık gösterebilmektedir (Kün vd., 1992), Nitekim Kumar vd., (2021) e-ISSN: 2148-2683 tarafindan kavuzsuz arpa genotipleri üzerinde yürütülen çalışmada, hektolitre ağırlığının $65.6-79.6 \mathrm{~kg}$ arasında değiştiği bildirilmiştir. Arpa üzerinde yapılan diğer çalışmalarda, hektolitre ağırlığının 62.6-68.4 kg (Sirat ve Sezer, 2009), 73.0-80.0 kg (Kilercioğlu, 2020) ve 71.24-81.11 kg (Köse vd., 2021) arasında değiştiği bildirilmiştir. Araştırmada genotiplerin hektolitre ağırlığı ortalamaları $68.04-78.44 \mathrm{~kg}$ arasında değişmiş ve denemede kullanılan tescilli çeşitlerden daha fazla hektolitre ağırlığına sahip hatlar belirlenmiştir.

\subsection{Bin Tane Ağırlığı}

Çalışmada genotiplerin bin tane ağırlığı 28.70-43.33 g arasında değişmiş, genotipler arasındaki bu farklılık istatistiksel olarak önemli bulunmuştur $(\mathrm{P} \leq 0.01)$. Kavuzlu arpa çeşitlerinde 1000-tane ağırlığı, kavuzsuz olarak denemeye alınan hatlardan daha fazla olduğu belirlenmiștir. En düşük 1000-tane ağırlığı INBYT-6 hattında belirlenmiş, ancak bu hat ile ABA-8 ve ABA7 hatları arasındaki farklılık önemli olmamıştır (Tablo 2). 


\section{European Journal of Science and Technology}

Bin tane ağırlığı verimi doğrudan etkilemekte olup, iklim şartlarına, bitkideki ana sap ve kardeş sayısına ve kültürel uygulaalara bağlı olarak değişebilmektedir (Kırtok ve Çölkesen, 1985; Kün, 1996). Kumar vd., (2021) tarafından 29 kavuzsuz arpa genotipi ile yürütülen bir çalışmada, bin tane ağırlığı $32.5-49.1 \mathrm{~g}$ arasında değişmiş ve tane doldurma oranı ile tane doldurma süresinin bin tane ağırlığını belirleyen önemli faktörler olduğunu bildirilmiştir. Araştırıcılar genel olarak kavuzsuz arpa genotiplerinin daha düşük verimli olduğunu, bunun nedenlerinden bir tanesinin de bin tane ağırlığının daha az olmasıyla ilişkilendirmişlerdir. Kilercioğlu, (2020) arpada bin tane ağırlığının lokasyonlara ve azot dozlarına göre değiştiğini bildirmiştir (Bursa lokasyonunda 41.73-45.37 g ve Balıkesir lokasyonunda ise 43.77-47.03 g). Kavuzsuz arpa genotiplerinde ortalama bin tane ağırlığı 45.26-60.82 g arasında değişmiştir (Özdemir, 2019). Farklı arpa genotiplerinde de bin tane ağırlığ 41.2-51.3 g olarak bildirilmiştir (Sirat ve Sezer, 2009). Ottekin vd., (1996) kavuzlu arpa genotiplerinde bin tane ağırlığının 40 g'ın üzerinde olduğunu, kavuzsuz genotiplerde ise bin tane ağırlığının daha düşük ve geniş bir varyasyon bulunduğunu (2943.3 g) bildirmişlerdir. Çalışma sonuçlarımıza göre kavuzlu genotiplerde bin tane ağırlığı daha yüksek, kavuzsuz genotiplerde daha düşük bulunmuş olup literatür ile uyumlu olduğu görülmüştür.

\subsection{Başakta Tane Sayısı}

Araştırmada arpa genotiplerine ait başakta tane sayıları 19.01-26.80 adet arasında değişmiştir. Genotiplerin başakta tane sayısı istatistiksel olarak \%1 seviyesinde önemli bulunmuştur $(\mathrm{p}<0.01)$. Araştırmada başakta tane sayıları tescilli çeşitlerde hatlardan daha yüksek olduğu belirlenmiştir. Tosun Paşa, Aydan Hanım ve Yalın çeşitleri istatistiksel olarak aynı grupta yer almıştır. En düşük başakta tane sayısı ise kavuzsuz ABA-7 hattında belirlenmiştir (Tablo 2).

Arpada başakta tane sayısı, tane verimini etkileyen önemli faktörlerden birisidir. Başaktaki tane sayısı fertil başakçık sayısı ile doğrudan ilişkilidir. Özellikle nisan ve mayıs aylarının serin geçmesi ve yeterli yağışın bulunduğu koşullarda başakta tane sayısı ve tane iriliği artmaktadir. Bu dönemin kurak ve sıcak geçmesi başakta steriliteyi arttırmakta ve dolayısıyla döllenmeyi olumsuz etkilemekte ve başakta tane sayısı azalmaktadır (Dencic vd, 1995; Şentürk ve Akgün, 2014). Başakta tane sayısının tane verimine doğrudan etkilediği ve bu etkinin yıllara ve genotiplere göre değiştiği bildirilmiştir (Kırtok ve Çölkesen, 1985; Yüksel ve İkincikarakaya 2020). Diğer çalışmalar incelendiğinde başakta tane sayıları, Bursa lokasyonunda 18.37-24.63 adet ve Balıkesir lokasyonunda 17.33-23.07 adet (Kilercioğlu, 2020), 25 farklı arpa genotipi ile yürütülen çalışmada 21.65-60.15 adet (Köse vd., 2021) arasında değiştiği bildirilmiştir.

Araştırmada başakta tane sayısının incelenen diğer araştırma sonuçları ile farklılıklar gösterdiği belirlenmiştir. Bu durum kullanılan genotiplerin farklı olması yanında çevre faktörlerinden de kaynaklanmaktadır.

\subsection{Ham Protein Oranı}

Araştırmada arpa genotiplerinin ham protein oranları \%12.58-15.75 arasında değişmiştir. Genotipler arasındaki bu farklılık istatistiksel olarak önemli bulunmuştur $(\mathrm{P} \leq 0.01)$. En yüksek ham protein oranı INBYT-6 ve ABA-7 hatlarında belirlenmiş ve istatistiksel olarak aynı grupta yer almıştır. En düşük ham protein oranı Tosun Paşa ve Yalın çeşitlerinde belirlenmiştir. Genel olarak denemede kullanılan kavuzsuz arpa hatlarının ham protein oranları, tescilli çeşitlerden daha yüksek oldukları saptanmıştır (Tablo 2).

Arpada protein oranı maltlık (düşük oranda) ve yemlik çeşitleri (yüksek oranda) ayırt etmek için kullanılmaktadır (Kün vd. 1992). Kavuzsuz arpa, insan gidası olarak kullanılması nedeniyle protein oranının yüksek olması istenmektedir. INBYT6 ve ABA-7 hatlarının protein oranlarının tescilli çeşitlerden daha yüksek olduğu belirlenmiş olup, bu hatlar insan beslenmesinde kullanılabilir. Ayrıca protein oranının genetik özelliklere, iklim koşullarına ve farklı kültürel uygulamalara bağlı olarak değişiklik gösterdiği bilinmektedir (Yüksel ve İkincikarakaya, 2020). Yapılan çalışmalar incelendiğinde protein oranları \%7.72-16.86 (Yüksel ve İkincikarakaya, 2020) ve \%12.02-15.09 (Özdemir, 2019) arasında tespit edilmiştir. Ottekin vd., (1996) tarafından yapılan çalışmada kavuzlu arpalarda protein oranının daha düşük ve dar bir varyasyonun bulunduğu (\%11.8-15.5), kavuzsuz arpaların ise daha yüksek protein oranına ve daha geniş bir varyasyona sahip olduğunu (\%13.2-19.5) ileri sürmüşlerdir. Çalışma sonuçlarımıza göre genotiplerin ham protein oranlarına ait değerler \%12.58-15.75 arasında yer almış ve denemede kullanılan çeşitlerden daha yüksek protein oranına sahip hatlar olduğu belirlenmiştir.

\section{Sonuç}

$\mathrm{Bu}$ çalışmada, kavuzlu ve kavuzsuz hat/çeşitler Isparta ekolojik şartlarında tane verimi, bazı verim öğeleri ve kalite özellikleri yönünden karşılaştırılmıştır. Özellikle son yıllarda popüler olan vegan/vejeteryan beslenme düzeni, insanları lif kaynakları ve protein oranları yüksek olan bitkisel ürünlere yönlendirmektedir. Arpa tahıllar arasında en düşük glisemik indekse ve yüksek oranda beta glukan (özellikle $\beta-1-3 ; 1-4$ ) içeriğine sahip olması nedeniyle insan beslenmesinde sağlıklı gida olarak önerilmektedir. INBYT-18 hattının tane veriminin yüksek ve ham protein oranının ise ortalamanın üzerinde olması, gıda olarak kullanılma potansiyelinin yüksek olduğunu göstermektedir.

\section{Teşekkür}

2021-YL1-0118 Nolu Proje ile tezimi maddi olarak destekleyen Isparta Uygulamalı Bilimler Üniversitesi, Bilimsel Araştırma Projeleri Yönetim Birimi Başkanlığı'na teşekkür ederim.

\section{Kaynakça}

Altındal, D. (2014). Göller Yöresinde Yetiştirilen Ekmeklik Buğday Çeşitlerinin/Populasyonlarının Genetik Uzaklıklarının Belirlenmesi Etkisi. Ziraat Mühendisliği, Doktora Tezi, Süleyman Demirel Üniversitesi, Isparta, Türkiye

Ames, N. P., Rhymer, C. R. (2008). Issues Surrounding Health Claims For Barley. The Journal of Nutrition, 138(6), 1237S$1243 \mathrm{~S}$.

Anonymous (1987). EBC Analysis by the European Brewery Convention Brauerei-und Getränke-rundschau. CH- 8047 Zurich Switzerland.

Anonim, (2019). FAO, Food and Agriculture Organization https://www.fao.org/faostat/en/\#data/QCL (erişim 09.10.2021).

Anonim, (2020). TUİK Bitkisel Üretim İstatistikleri. https://data.tuik.gov.tr/Kategori/GetKategori?p=tarim-

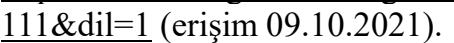




\section{Avrupa Bilim ve Teknoloji Dergisi}

Baydilli, M. (2017). Şanlıurfa İli Hilvan İlçesinde Kuru Koşullarda 10 Arpa Çeşidinin Verim ve Performanslarının Karşılaştırılması Ziraat Mühendisliği, Yüksek Lisans Tezi, Harran Üniversitesi, Şanlıurfa, Türkiye

Bremner, J. M. (1965). Organic forms of nitrogen. Methods of Soil Analysis: Part 2 Chemical and Microbiological Properties, 9, 1238-1255.

Çöken, İ., Akman, Z. (2016). Isparta Ekolojik Koşullarında Bazı Arpa (Hordeum Vulgare L.) Çeşitlerinin Verim ve Kalite Özelliklerinin Belirlenmesi. Süleyman Demirel Üniversitesi Fen Bilimleri Enstitüsü Dergisi, 20(1).

Dencic, S., Kastori, R., Kobiljski, B., Petrovic, M. (1995). Influence of drought on Morphologic and Agronomic Traits. Institut za ratastvo i povrtarstvo 23, 203-211.

Derakhshani Z, Malherbe, F. Panozzo, J.F., Bhave, M. (2020). Evaluation of Diverse Barley Cultivars and Landraces for Contents of Four Multifunctional Biomolecules with Nutraceutical Potential. Current Research in Nutrition Food Science Bhopal 8(2), 38-390.

Ergün, N., (2005). İleri Kademe Arpa (Hordeum Vulgare L.) Hatlarinda Verim Ve Verime Etkili Bazı Karakterlerin İncelenmesi. Ziraat Mühendisliği, Yüksek Lisans Tezi, Ankara Üniversitesi, Ankara, Türkiye

Genç, İ., Ülger, A.C., Yağbasanlar, T., Kırkok, Y., Topal, M. (1988). Çukurova Koşullarında, Triticale, Buğday ve Arpanın Verim ve Verim Öğeleri Üzerinde Kıyaslamalı Bir Araştırma. Çukurova Üniversitesi, Ziraat Fakültesi Dergisi 3(2), 1-13.

Gökgöl M., 1969. Serin İklim Hububatı Ziraatı ve Islahı (Buğday, Çavdar, Arpa Ve Yulaf). Tarım Bakanlığı Ziraat İşleri Genel Müdürlüğü. 407 s. Özaydın Matbaası, İstanbul

Harlan, J. R., Zohary, D. (1966). Distribution of Wild Wheats and Barley. Science, 153(3740), 1074-1080.

Kacar B, Inal, A. 2010. Bitki Analizleri. Nobel No:1241, Ankara

Karaduman, Y. (2006). Kavuzsuz Arpa Potansiyeli. Unlu Mamuller Tek. Dergisi, 74, 21-26.

Kırtok, Y., Çölkesen, M. 1985. Çukurova Koşullarında Denemeye Alınan Arpa Çeşitlerinde Önemli Bazı Verim Unsurları Üzerinde Path Katsayısı Analizi. Doğa Bilim Dergisi, 9 (1)

Kilercioğlu, B. (2020).Güney Marmara Koşullarında Farklı Azot Dozlarının Kavuzsuz Arpa Çeşidinin (Hordeum vulgare L. var. nudum hook. ef.) Verim ve Verim Öğeleri Üzerine Etkisi. Ziraat Mühendisliği, Yüksek Lisans Tezi, Uludağ Üniversitesi, Bursa, Türkiye

Köse E. D., Ö., Mut, Z., Kardeş, M, Y. (2021). Bilecik Koşullarında Kavuzsuz Arpa Genotiplerinin Tane Verimi ve Bazı Kalite Özelliklerinin Belirlenmesi. ISPEC Journal of Agricultural Sciences, 5(3), 608-615.

Kumar, D., Verma, R. P. S., Narwal, S., Singh, J., Malik, R., Kharub, A. S., Singh, G. P. (2021). Identification of Promising Sources of Hulless Barley (Hordeum vulgare L.) For Important Quality Traits. Journal of Cereal Research, 13(2).

Kün, E. (1996). Tahıllar-I (Serin İklim Tahılları). Ankara Üniversitesi Ziraat Fakültesi Yayın No: 1451. Ders Kitabı:431, Ankara.

Kün E, Özgen M, Ulukan H. (1992). Arpa Çeşit ve Hatlarının Kalite Özellikleri Üzerinde Araştırmalar. II. Arpa-Malt Semineri, 25-27 Mayıs 1992, Konya, 70-95.

Madhujith, T., Shahidi, F. (2007). Antioxidative and Antiproliferative Properties of Selected Barley (Hordeum vulgarae L.) Cultivars and Their Potential for Inhibition of Low-Density Lipoprotein (LDL) Cholesterol Oxidation. Journal of Agricultural and Food Chemistry, 55(13), 50185024.

Mut, Z., Sirat, A., Sezer, İ. (2014). Samsun Koşullarında Bazı İki Siralı Arpa (Hordeum Vulgare conv. distichon) Genotiplerinde Tane Verimi İle Başlıca Tarımsal Özelliklerin Belirlenmesi ve Stabilite Analizi.Yüzüncü Yıl Üniversitesi Tarım Bilimleri Dergisi, 24 (1), 60-69.

Narwal, S., Kumar, D., Verma, R. P. S. (2016). Effect of Genotype, Environment and Malting on the Antioxidant Activity and Phenolic Content of Indian Barley. Journal of Food Biochemistry, 40(1), 91-99.

Nesbitt, M., Samuel, D. (1996). Archaeobotany in Turkey: A Review of Current Research. Orient-Express, 3, 91-96.

Ottekin, A., Akar, T., Tosun, H., Ozan, A. N., Demir, Z. (1996). Kavuzsuz Arpanın Tarımsal ve Teknolojik Özelliklerinin Belirlenmesi. IV. Ulusal Nükleer Tarım ve Hayvancılık Kongresi, Tebliğ Özetleri, Bursa, s.29.

Özdemir., A. (2019). Kavuzsuz Arpa (Hordeum vulgare L. var. nudum)Genotiplerinde Kışlık ve Yazlık Ekimin Verim ve Bazı Agronomik Özellikler Üzerine Etkisi. Ziraat Mühendisliği, Yüksek Lisans Tezi, Selçuk Üniversitesi, Konya, Türkiye

Öztürk, A., Çağlar, Ö., Tufan, A. (2001). Bazı Arpa Çeşitlerinin Erzurum Koşullarına Adaptasyonu. Atatürk Üniversitesi Ziraat Fakültesi Dergisi,32(2), 109-115.

Sağsöz, S. (2000). Tohumluk Bilimi. Atatürk Üniversitesi Yayınları, 677, 188s., Erzurum.

Sarkar, P., Lohith Kumar, D. H., Dhumal, C., Panigrahi, S.S., Choudhary, R. (2015). Traditional and Ayurvedic Foods of Indian Origin. Journal of Ethnic Foods 2; 97-109

Sirat, A., Sezer, İ. (2009)., Bafra Ovası Koşullarına Uygun (Hordeum vulgare L.) Çeşitlerinin Belirlenmesi.Anadolu Tarım Bilimleri Dergisi,2 4(3), 167-173.

Şentürk, Ş., Akgün, İ. (2014). Bazı Tritikale Genotiplerinin Batı Geçit Bölgesinde Verim ve Verim Unsurlarının Belirlenmesi. Süleyman Demirel Üniversitesi Ziraat Fakültesi Dergisi, 9(1), 16-26.

Ullrich, S. E. (2011). Significance, Adaptation, Production, and Trade of Barley. In: Ullrich SE, Editor. Barley: Production, Improvement, and Uses. Oxford: WileyBlackwell. pp. 3-13.

Ulupınar, Ü. (2017). Isparta Koşullarında Makarnalık Buğday (Triticum durum desf.) Çeşitlerinin Adaptasyonu ve Farklı Azot Dozu Uygulamalarının Verim ve Verim Unsurlarına Etkisi. Ziraat Mühendisliği, Yüksek Lisans Tezi, Süleymen Demirel Üniversitesi, Isparta,Türkiye

Yüksel, S. (2017). Bazı Kavuzsuz Arpaların ( Hordeum Vulgare L. var. nudum Hook. F.) Gelişme Dönemleri ile Verim ve Verim Öğelerinin Belirlenmesi. Ziraat Mühendisliği, Doktora Tezi, Ankara Üniversitesi, Ankara,Türkiye

Yüksel, S., İkincikarakaya Ü. S. (2020). Bazı Kavuzsuz Arpaların (Hordeum Vulgare L. var. Nudum Hook. f.) Verim ve Bazı Kalite Özelliklerinin Belirlenmesi. Kahramanmaraş Sütçü İmam Üniversitesi Tarım ve Doğa Dergisi, 23(3), 705-712. 